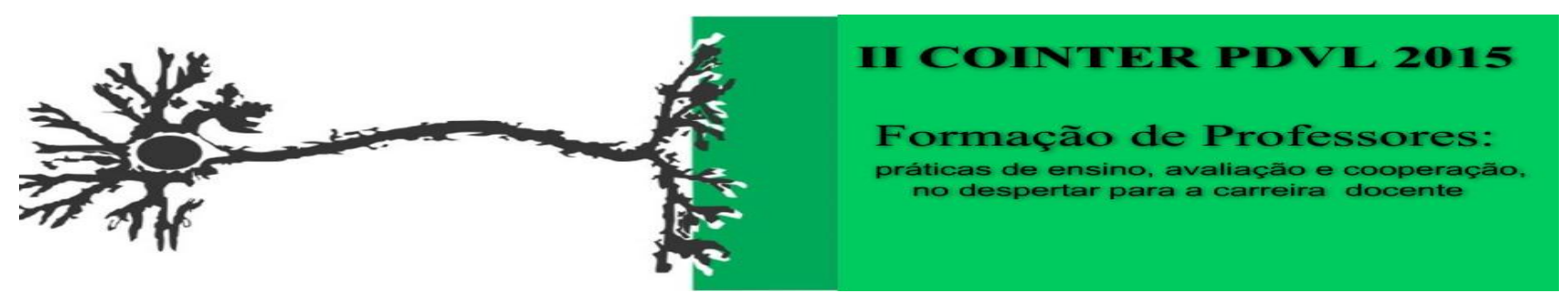

\title{
PRINCIPAIS DESAFIOS ENCONTRADOS NA COORDENAÇÃO DO ENSINO SUPERIOR DO IF SERTÃO PE, CAMPUS PETROLINA
}

\author{
Apresentação: Relato de Experiência \\ Viviane de Souza ${ }^{1}$; Albertina Marília Alves Guedes²
}

\section{Introdução}

Competências meramente acadêmicas não bastam ao coordenador. Entendendo que cabe a este o compromisso de auxiliar os professores em sua prática, favorecendo, sobremaneira, a reflexão e a criticidade, o Coordenador de Ensino Superior, similar ao Coordenador Pedagógico, deve oferecer não só a mediação entre o coordenador de curso e as diversas instâncias educacionais, como também deve garantir que as diretrizes institucionais sejam observadas (TARDIF, 2002). Além disso, a Lei de Diretrizes e Bases da Educação Nacional apresenta que "a educação (...) tem por finalidade o pleno desenvolvimento do educando, seu preparo para o exercício da cidadania e sua qualificação para o trabalho" (BRASIL, 1996, 34).

\section{Relato de Experiência}

Este trabalho diz respeito a um relato de experiência vivenciado no ano 2013-2014 no qual as autoras desenvolveram atividades de Gestão na Coordenação de Ensino Superior no IF Sertão PE, Campus Petrolina. Ressalta-se que no Campus Petrolina há curso de Licenciatura em Música, Licenciatura em Computação, Licenciatura em Química e Licenciatura em Física. Desse modo, a problemática que propiciou este relato de experiência foi a seguinte questão: Quais podem ser os principais desafios e/ou dificuldades em desenvolver atividades de Gestão no Departamento de Ensino Superior dos cursos de Licenciatura visando promover a interação entre os cursos de licenciatura do IF Sertão PE, Campus Petrolina?

Assim sendo, durante o período de 2013-2014 foram encontrados diversos desafios em desenvolver atividades relacionadas à Gestão dos cursos de licenciatura os quais visavam promover,

\footnotetext{
${ }^{1}$ Técnico em Assuntos Educacionais do IF Sertão PE, Campus Petrolina. E-mail: viviane.souza@ifsertao-pe.edu.br

${ }^{2}$ Professora de Psicologia nos cursos de Licenciatura do IF Sertão PE. E-mail: albertinamarilia@hotmail.com
} 
principalmente, uma melhor comunicação e interação entre todos os cursos de licenciatura do Campus Petrolina.

Algumas das dificuldades encontradas estão relacionadas à supervalorização dos conteúdos técnicos, por parte dos próprios professores das disciplinas da área técnica em detrimento dos conteúdos da área pedagógica. Tal supervalorização era tão presente e constante que, muitas vezes, implicava na desvalorização do trabalho do coordenador pedagógico, por parte dos professores das áreas técnicas.

Outra dificuldade encontrada pela Gestão relacionada à supervalorização aos conteúdos das áreas técnicas refere-se ao fato de alguns coordenadores e professores dos cursos de Licenciatura não terem formação em Licenciatura e, consequência disso, dificultava ainda mais o diálogo entre os mesmos e a coordenadora pedagógica do Departamento de Ensino Superior, bem como com Gestão deste setor. Além disso, visto que muitos desses professores são Bacharéis e não Licenciados dificultava, em alguns momentos, até mesmo a relação professor-aluno em sala de aula.

\section{Considerações Finais}

A partir dessa experiência percebe-se que é primordial refletir sobre a necessidade de formar docentes que atentem não apenas para a dimensão técnica presente em alguns cursos de licenciatura, tais como nos curso de Licenciatura em Química e Licenciatura em Física, mas perceba também a Dimensão Humana tão bem discutida pelos professores das disciplinas pedagógicas presentes nos cursos de licenciatura.

Além disso, conforme apresenta Tardif (2002, p. 36) é importante que o professor que leciona em cursos de formação de professores "pode-se definir o saber docente como um saber plural, formado pelo amálgama, mais ou menos coerente, de saberes oriundos da formação profissional e de saberes disciplinares, curriculares e experienciais".

\section{Referências}

TARDIF, M. Saberes docentes e formação profissional. Petrópolis: Vozes. 2002.

BRASIL. Lei de Diretrizes e Bases da Educação Nacional, n 9394, de 20 de dezembro de 1996. 